\title{
SANTA CLARA,
}

PADROEIRA

\section{DA TELEVISÃO'}

Santa Clara, padroeira da televisão

Que o menino de olho esperto saiba ver tudo

Entender certo o sinal certo se perto do encoberto

Falar certo desse perto e do distante porto aberto

Mas calar

Saber lançar-se num claro instante.

Santa Clara, padroeira da televisão

Que a televisão não seja o inferno, interno ermo,

Um ver no excesso o eterno quase nada (quase nada)

Que a televisão não seja sempre vista

Como a montra condenada, a fenestra sinistra

Mas tomada pelo que ela é

De poesia.

Quando a tarde cai onde o meu pai

Me fez e me criou

Ninguém vai saber que cor me dói

E foi e aqui ficou

Santa Clara

Saber calar, saber conduzir a oração

Possa o vídeo ser a cobra de outro éden

Porque a queda é uma conquista

$\mathrm{E}$ as miríades de imagens suicídio

Possa o vídeo ser o lago onde Narciso

Seja um deus que saberá também

\section{Ressuscitar}

Possa o mundo ser como aquela ialorixá

A ialorixá que reconhece o orixá no anúncio

Puxa o canto pra o orixá que vê no anúncio

No caubói no samurai no moço nu na moça nua

No animal na cor na pedra vê na lua vê na lua

Tantos níveis de sinais que lê

E segue inteira.

\section{O AUTOR}

\section{Caetano Veloso}

Cantor e compositor, nasceu em 1942, na cidade de Santo Amaro da Purificação, BA. Em Salvador, toma contato com as obras de Dorival Caymmi e Luiz Gonzaga. Em 1965. apresenta Boa Palavra, no Festival de Música da TV Excelsior. No ano seguinte, vence com Um Dia, no Festival da TV Record. Seu primeiro disco, Domingo, sai em 1966 , com Gal Costa. Gravou também Doces Bárbaros (1976), Cores e Nomes (1982), Estrangeiro (1989), Circuladô (1991), entre tantos outros. Sua primeira incursão no cinema foi em Cinema Falado (1986).

1. Composição musical de Caetano Veloso. LP Caetano Veloso Circuladô. Produzido por Arto Lindsay. Rio de Janeiro/Nova Iorque: Polygram/East Hill Studios, 1991. 